ARTICLE

Received 12 Jul 2016 | Accepted 23 Sep 2016 | Published 18 Oct 2016

DOI: $10.1057 /$ palcomms.2016.76

\title{
"Not to come near our person by ten mile": London, plague and spatial relations in 2 Henry IV
}

Katie Knowles ${ }^{1}$

\begin{abstract}
Unlike many of his contemporaries, Shakespeare rarely set his plays in London and those of his plays that are partially set in the capital do not seem particularly interested in their location. Consequently studies of early modern London in Renaissance drama have tended to focus on the city comedies, or on those of Shakespeare's plays where another city (Rome, Athens, Venice and so on), might be argued to "stand in" for or shadow early modern London and its concerns. Shakespeare's histories, therefore, have not featured as prominently in discussions of dramatic presentations of early modern London as they deserve to. This article suggests that 2 Henry IV is deeply concerned with what Henri Lefebvre termed "the production of space", but that it is not in its location of scenes in Eastcheap or Westminster that this play reveals its immersion in the early modern London of its production, but in its discourse of disease, its imagery of boundaries and containment, and its repeated evocation of fluid and equivocal spaces, including the tavern, the battlefield and the crown itself. It reads the play's imagery of contradictory, ambiguous and transformative spaces, and of boundaries being set up and broken, as implicitly engaged with contemporary preoccupations with London's shifting cultural and geographical identity, the growth and character of the suburbs, and particularly with fears about plague and its transmission across city spaces. It concludes that the fluid nature of urban space, and the artificial nature of boundaries are brought into focus by crises such as plague, and that the play's discourse of contagion can be read as an illuminating backdrop to its emphasis on changeable and disorienting spaces. This article is published as part of a collection to commemorate the 400th anniversary of Shakespeare's death.
\end{abstract}

\footnotetext{
${ }^{1}$ University of Liverpool, Liverpool, UK
} 


\section{Introduction}

he topographical and demographic changes experienced by London during the sixteenth and seventeenth centuries are well-documented and need only brief repetition. Grantley (2008: 14-15) notes that "[b]y the mid sixteenth century London had spread considerably beyond the old walled city in various directions", and Manley (1995: 126) reports that "London's government and jurisdiction, which represented 80 percent of the greater population in 1560, represented less than half of it by 1630. The suburbs with their population of casual labourers and unassimilated artisans, immigrants and paupers, were outstripping the City of London in growth". A great deal of interesting critical work has been done in the last 20 years on the interplay between the cultural geography ${ }^{1}$ of early modern London and Renaissance drama, the ways in which contemporary plays represented and intervened in their audiences' relationships with and constructions of urban spaces and specifically with the rapid and potentially disorienting "economic, social, and cultural changes that were transforming the face of London" (Mullaney, 1988: 15). ${ }^{2}$ Jean Howard (2009: 2) states succinctly that "[a]t the theater Londoners encountered fictions that directly addressed the conditions of social change and dislocation occurring around them."

Understandably, much of this work has focused on city comedies (sometimes called London comedies)-a genre which, as Howard (2009: 2) says, "directly address the urban milieu"-or on plays in which characters' relationships to a city state other than London play a prominent role. ${ }^{3}$ Indeed, the prevalence of city comedies in criticism on early modern cultural geography led Janette Dillon to open her 2000 monograph, Theatre, Court and City, 1595-1610: Drama and Social Space in London, with the wry disclaimer, "[t]his is not another book on city comedy" (Dillon, 2000: 1). This focus on the city comedies is unsurprising: emerging at the very end of the sixteenth century and becoming established in the first decade of James I's reign, the genre's overt focus on London locations, and citizen concerns and stereotypes was unparalleled. This focus is exemplified by the Prologue of Jonson's The Alchemist (1610):

Our scene is London, 'cause we would make known,

No country's mirth is better than our own:

No clime breeds better matter for your whore,

Bawd, squire, impostor, many persons more,

Whose manners, now call'd humours, feed the stage ... (Prologue, 5-9)

For scholars interested in dramatic representations of late sixteenth and early seventeenth-century London, the city comedies, popularised by Jonson, Marston and Middleton, among others, offer a wealth of material.

Relatively little has yet been said, however, about the role of London's cultural geography in Shakespeare's chronicle history plays-his only plays, apart from The Merry Wives of Windsor, to be set wholly in England and partially in London. Grantley (2008: 52), for example, comments that while late Elizabethan playwrights "producing material for the commercial theatre increasingly use London as a setting, [...] Shakespeare and Marlowe are notable and curious exceptions to this tendency", except when, in their history plays, "both playwrights are obliged by the historical material to use London as a setting", while Munro (2005: 76) has acknowledged that "[t]he apparent insularity of the London of the history plays feeds into a critical tendency to treat what we would call theatrical setting in uncomplicated terms, as a neutral fictive world that frames the action of the play".
There are, of course, exceptions to this neglect. Munro has productively challenged the tendency he identified "to treat $[\ldots]$ the theatrical setting in uncomplicated terms" by addressing such questions as, "How does the space of the urban play relate to the urban space of its performance? How was the space of early modern London imagined, constructed, and contained, especially in the official and commercial drama of the period? How does Shakespeare's construction of London interact with those prevailing spatial ideologies?” (Munro, 2005: 77), while Turner (2006) has also engaged with the spatial concerns of Shakespeare's history plays, arguing that "the history plays become increasingly spatial, rather than chronological, in their imagery, as Shakespeare moves from the first to the second tetralogy" (238), and remarking how, in 2 Henry $I V$, the rebels discuss their uprising in a passage that is "remarkable for the way in which it figures treachery, political intrigue, and state-building in terms that might have been drawn directly from the surveying and building manuals that were circulating throughout English culture" (Turner, 2006: 239). Munro's focus, however, is primarily on crowds and population growth, while Turner is interested specifically in the relationship between Renaissance drama and what he calls "the practical spatial arts", focusing on imagery of plotting, surveying and mapping, and on the ways in which "Shakespeare $[. .$.$] viewed geometrical and mathematical projec-$ tion as fundamental to theatrical representation" (Turner, 2006: 240). Hannah J. Crawforth, Sarah Dustagheer and Jennifer Young's recent book Shakespeare's London, makes a fascinating and accessible contribution to the field, tracing "important metaphorical connections between Shakespeare's London and the world of his plays" across the range of genres, with each of the eight chapters focusing on "one play and one key location, drawing out the thematic connections between that place and the drama it informs" (Crawforth et al., 2015: 14), but it makes only brief reference to the Henry IV plays, instead turning to Richard II and Henry VIII as its examples of history plays, and reading them as thematically connected to Whitehall and The Tower of London, respectively. Dillon's (2012) book, Shakespeare and the Staging of English History, on the other hand, engages in detail exclusively with the history plays, but its spatial focus not primarily on the urban spaces their audiences inhabited outside the theatre, but with the space of the stage and the positioning and movement of bodies and objects on stage, looking "closely at repeated units of action or stage pictures" (12).

Shakespeare spent the vast majority of his working life in London. He lived in the city, wrote for playing companies established in the city, and for audiences familiar with the city, and in his history plays he made use of London locations and institutions: this immersion in London life cannot have failed to influence his work. It seems to me, then, there is much more to say about the way that Shakespeare's histories relate to the city in which they were written and first performed, and that the Henry $I V$ plays in particular have perhaps not received as much critical attention in relation to spatial issues as they deserve, because they fall between two stools in the way in which they represent London: they use the city as a setting, but do not focus on it or engage with it as directly as, say, the city comedies do, and so are often ignored by critics interested in how London locations are directly represented on the Renaissance stage. On the other hand, because they are at least partially set in London, they are also often sidelined by critics interested in how other locations or incidents shadow London locations or concerns in Shakespeare's plays. They are simultaneously too much and too little "about" London to easily suit either approach.

Dustagheer (2013: 574), in an valuable survey of the "spatial turn" in Renaissance studies, comments that "spatial theory establishes that spaces consist of social practices and experiences, 
and such arguments allow a re-examination of the seeming lack of London locations staged and referred to in Shakespeare's plays. Rather than literal representations, in several cases scholars have established that it is the social practices, ideologies and experiences from the city which surrounded him that Shakespeare dramatises". This article approaches 2 Henry IV from this perspective, concurring with Sanders' (2011) statement that "drama was one of the key means by which early modern English society strove to make sense of space" (9), and applying it to a chronicle history play in a broader and more conceptual way than is usual in studies of early modern London. I suggest that "making sense of space" is not only achieved by directly reproducing or discussing contemporary London locations on stage, but also by a more subtle interplay of linguistic patterns, imagery and character interactions which coalesce to resonate with the ways in which early modern Londoners experienced the spaces of their city. A play does not need to be overtly about London, or indeed any other city, to reveal aspects of the early modern city's cultural geography, a point Crawforth et al. (2015: 2) make very succinctly when they assert that "London holds a central place in the Shakespearean imagination, underwriting the plays that he created there, even while they are set elsewhere". I would go further, however, and suggest that London also underwrites 2 Henry $I V$ in this way-a play which is set partly in London, but does not seem explicitly interested in its London locations.

2 Henry IV is, of course, medieval in its setting and sonominally at least-historically removed from the context of its original audiences. It is also less obviously "place-based" (Howard, 2009: 3) than many of the London comedies: while specific English settings are used-Eastcheap, Westminster, Gloucestershire, Gaultree-it does not conjure up sixteenthcentury London locations and preoccupations with the vividness or specificity of, say, Jonson's Bartholomew Fair, or Dekker's The Shoemaker's Holiday. Yet 2 Henry IV is deeply concerned with what Henri Lefebvre (1974) termed "the production of space" and particularly with the concept of "social space" that he defined: Lefebvre argues that "Social spaces interpenetrate one another and/or superimpose themselves upon one another. They are not things, which have mutually limiting boundaries and which collide because of their contours or as a result of inertia. [...] Visible boundaries, such as walls or enclosures in general, give rise for their part to an appearance of separation between spaces where in fact what exists is an ambiguous continuity" (Lefebvre, 1974: 86-87). 2 Henry IV teems with imagery of contradictory, ambiguous and transformative spaces, and of boundaries being set up and broken, in a way which engages implicitly with contemporary preoccupations with London's shifting cultural and geographical identity and particularly with the fears about contagion and disease, specifically plague, which went hand-inhand with concerns about population growth and over-crowding, and were a key factor in transforming citizens' perceptions and experiences of the spaces of the city. This article does not seek to identify how specific locations or events may have informed this drama, rather it aims to uncover how 2 Henry IV contains traces of the "spatial relations" of early modern urban life-that is the multiple ways in which early modern Londoners may have experienced and related to their civic and domestic spaces in various circumstances. ${ }^{4}$ This article will argue that around $1598^{5}$ -the year that, as Stanev (2014: 15) notes, "welcomed the first city comedies [and] the antiquarian John Stow published [...] his Survey of London"-Shakespeare presented playgoers with a chronicle history, which resonated with some of the desires and fears bound up with the urban spaces they occupied, negotiated and produced. It will suggest that the fluid nature of urban space, and the artificial nature of boundaries between spaces are brought into focus by crises such as plague, and that the play's discourse of contagion can be read as an illuminating backdrop to its emphasis on transformative and equivocal spaces.

\section{"Now, neighbour confines, purge you of your scum!": representations of migration, over-crowding and the "sinfully polluted suburbs" in 2 Henry IV}

In Act 4 of 2 Henry IV, when the ailing King imagines the fate of his kingdom under the rule of his wayward son, Prince Hal, his fears are expressed in imagery of movement and transformation. An outflow of worthy, wise nobles is matched by an influx of undesirable and criminal people in an exchange which transforms the court from a space of order and gentility into a space of chaos and disorder:

Harry the Fifth is crowned. Up, vanity!

Down, royal state! All you sage counsellors, hence!

And to the English court assemble now

From every region, apes of idleness!

Now, neighbour confines, purge you of your scum!

Have you a ruffian that will swear, drink, dance,

Revel the night, rob, murder, and commit

The oldest sins the newest kind of ways? [...]

England shall give him office, honour, might;

For the fifth Harry from curbed licence plucks

The muzzle of restraint ... $(4.3 .248-260)^{6}$

In Act 5, when Hal ascends the throne as Henry V, however, this feared influx is not realised. In fact, Henry banishes Falstaff - "the tutor and feeder of [his] riots" (5.5.62)-commanding him "on pain of death, [...] Not to come near our person by ten mile" (5.5.63-5). In his banishment of his old companion, Henry creates a protected space around himself; a magic circle of propriety into which the riotous Falstaff cannot encroach, the antithesis of the invasion of "scum" and "ruffian[s]" that his father dreaded.

In its anxiety about uncontrolled movement of people changing the nature of the English court, Henry IV's speech echoes expressions of unease at London's rapid population growth and geographical expansion during the sixteenth century - growth which lead to a royal proclamation in 1580 "against new building or subdividing of houses in London and its environs" (Munro, 2005: 15), and specifically focused on the social and moral threat and economic burden posed by migrants to the city. ${ }^{7}$ A subsequent proclamation by James I, soon after his accession in 1603 and during a particularly virulent outbreak of plague, reiterated the crown's attempt to halt the rapid growth of the suburbs, ordering "the emptying and pulling down of suburban tenements, which had become the haunt of 'excessive numbers of idle, indigent, dissolute and dangerous persons'" (Howard, 2009: 122). Like Henry IV's speech, late sixteenth and early seventeenth century written depictions of the city were often characterized not just by an anxiety about growing population, but also by anxiety specifically about movement of people changing the character and topography of the city. Stanev (2014: 65) quotes James Howell who "remarked that '['t] is true that the suburbs of London are much larger than the body of the city... which made the Spanish Ambassador to say ... "I believe there will be no City left shortly, for it will all run out of the gates to the suburbs"'". Plague epidemics only heightened anxiety about movement of people-and particularly the kind of people Henry IV imagines invading the English court: Slack (1990: 45) notes that "[f]rom the epidemic of 1593 onwards, English writers [...] began to refer to the obligations of magistrates during epidemics. They should keep their cities clean to prevent 
infectious miasmas, and above all they should guard against the transmission of infection from person to person. They could prevent the movement into their towns of strangers, and especially of vagrants, from infected localities". Henry IV's use of the medical term "purge" to describe the movement of undesirables from "neighbour confines" to the English court, with its suggestion that the removal of such people would act as a medical cleansing, reinforces the implicit link between physical illness and moral failings that underpinned early modern understanding of disease, as Slack describes:

Since the disease apparently took so many different forms, it is not surprising that a complex chain of explanation and a large variety of remedies were provided for it. Neither is it surprising that so severe and unpredictable a disease was universally assumed to have a supernatural origin. [...] God sent plague just as he sent any other form of natural disaster against the sins of mankind. Particular epidemics were therefore to be explained by national vices, such as swearing, negligence in attending church, atheism, play-going, covetousness and extravagant female fashions. (Slack, 1990: 26).

Henry V's 10 mile exclusion zone, on the other hand, suggests a sort of fantasy of impermeability; a demarcation separating the orderly from the disorderly, neatly excluding the outlaw practices represented by Falstaff and keeping them at a safe distance. In this respect, Henry V's exclusion zone, and its relationship to Falstaff, echoes the oft-repeated and simplistic understanding of the relationship between the early modern City of London proper, and its Liberties and suburbs in which, Mullaney (1988: 22) argues,

alongside gaming houses, taverns, bear-baiting arenas, marketplaces, and brothels, stood monasteries, lazar-houses, and scaffolds of execution. Whatever could not be contained within the strict bounds of the community found its place here, making the liberties the preserve of the anomalous, the unclean, the polluted, and the sacred.

If Henry IV's dire warning about his son's reign imagines a scenario in which the stereotypical behaviour associated with the suburbs makes an incursion into the city proper, flooding from the periphery to the centre, then Henry V's banishment of Falstaff suggests the possibility of holding back that tide-of successfully exiling the "idle, indigent, dissolute and dangerous" Falstaff to the margins of a circular space that is defined by a ten-mile separation from the king, who is its centre. Indeed, although the imagery of disease which recurs throughout the play is not present at this point, it is tempting to read Henry's banishment of Falstaff as a kind of quarantining or isolation of the king, keeping him separate from the morally infections influence of Falstaff. Thus, these two moments in 2 Henry IV offer a model of how the play engages implicitly with spatial concerns and issues recognizable to its early modern London audience, without directly referencing the city, the suburbs, or the question of migration, over-crowding and contagion, but they do so in a way which is uncharacteristically clear-cut, pitting an image of total infiltration against and image of successful exclusion. Elsewhere in the play, rather than offering up two opposing images, which might be related to ways of viewing the urban space of early modern London, Shakespeare tends to present more equivocal images which shift and transform, a concept which itself can be usefully applied to the relationship between the city of London and its suburbs.

The idea of a stable, binary distinction between the city and its extra-mural suburbs and liberties outlined by Mullaney, has been successfully challenged by critics such as Ward (1997: 25-26), who argues that while the relationship between the two areas was sometimes "marked by tension", attitudes of Londoners to the greater metropolitan area were complex and by no means homogenous, and that "ideologically there was no reason why Londoners could not have embraced the suburbs and liberties as integral parts of the community in which they lived, worked, played, and prayed". Indeed several studies have suggested that the idea that "anomalous" or disorderly practices were banished to the suburbs has itself been overstated. Newman (2007: 135), for example, notes that "though both royal edict and city authorities repeatedly banished prostitutes and brothels from within the city, both Ian Archer and Paul Griffiths [...] have shown a startling number of establishments within the City". ${ }^{8}$ Certainly, as many critics have pointed out, London's suburbs "had a reputation as a place of disease, poverty, and social instability" (Turner, 2006: 187), and they were often associated with both moral contagion (as the home of brothels and playhouses), and physical contagion (they were the historical sites of hospitals and lazar houses, and they were often cited as the origin of plague epidemics). ${ }^{9}$ Yet to view the relationship of City and suburbs as fixed-either as one of order versus disorder, what Monteyne (2007: 85) describes as "the image of a healthy metropolis surrounded by afflicted suburbs", or, conversely, as one of untroubled metropolitan community-would be to ignore the extent to which such spaces are dynamic and in flux; shifting their meaning depending on context and perspective. As Dillon argues,

Cities, as Braudel emphasises, want to be worlds apart, and their investment in marking and policing boundaries is enshrined in law and ritual as well as in the building of physical defences. Yet the boundaries are never as firmly fixed as cities want them to be, and individuals experience the spaces of city and not-city in ways that are more fluid than walls, laws and rituals might seem to indicate. [...] If the liberties look like the interstices where the city's dirt collects, it is primarily because that is how the city, with its desire for clearly marked boundaries, wants them to look (Dillon, 2000: 97).

"Desire for clearly marked boundaries" is a phrase, which succinctly characterizes both Henry IV's and Henry V's positions at the close of the play. Henry IV fears the dissolution of boundaries between king and commoner, and articulates this fear through imagery of the invasion of the court by a mass of ruffians, while Henry V seems to successfully impose a boundary by his banishment of his "misleaders". But this desire for clearly marked boundaries is complicated and undermined by the preceding three acts of the play in which the fluidity of individual experience noted by Dillon in relation to urban space comes to the fore, and which suggest, at every turn, that such boundaries and demarcations are not to be relied upon.

Here, Emma Katherine Atwood's discussion of dramatic space is a useful point of reference. Atwood (2013: 51-52) outlines three categories of space in drama: "performance space" (the literal boards and furniture of the stage); "representational space" (the fictional world created by the actors-a forest, a castle, a tavern etc.); and "imaginative space":

Imaginative space [...] offers possibilities as to how representational space should or could be envisioned and thus how performance space should or could be transformed. [...] Imaginative space can be suggested to an audience by dramaturgical, staging, and acting choices, but ultimately it is up to each audience member to produce his or her own imaginative space for the play. Imaginative space is often emotional and always 
plural, and thus accounts for the subjective experience of space both in the playhouse and beyond.

While there is of course more scope for plurality of imaginative space in drama than in real life, the concept can productively be applied to the civic space of early modern London. Different individuals and groups conceived of various urban spaces differently. The imaginative space of the city was not fixed: it could shift, not only between the perceptions of different groups and individuals, but possibly within them too, depending on context and circumstance. To puritans the liberties and suburbs might have been sinful and polluted because of their association with playhouses and bawdy houses, but they were also a "safe haven" where they and "other non-conformist groups could pursue their desired form of worship" (Dillon, 2000: 98); to the tradesmen who operated there outside the city's guild system or the actors who performed in the playhouses they were, perhaps, places of opportunity and relative freedom. Crucially, though, crises like plague epidemics could change the imaginative space of the city: for early modern Londoners in search of a good time, the aptly named Liberties to which they could resort for the slightly subversive pleasures offered by playhouses, prostitution and bearbaiting could-in plague time-come to be not merely subversive or thrilling but outright dangerous; places of contagion, outlawed and avoided. As Munro (2005: 176) says, "the advent of plague means the death of the festive life of the city: pageants and ceremonies are cancelled, theaters closed, and the gathering of crowds forbidden", and Sanders (2011: 195) suggests that "[t]he anxieties of particular communities around illness could serve as cohering beliefs at times of particular crisis, such as plague, and therefore contribute to particular senses of neighbourhood". An awareness of the city's responses to epidemic disease and their impact on the experience of urban space can therefore illuminate 2 Henry IV's spatial imagery.

\section{Reconfigured spaces: plague as backdrop to 2 Henry IV}

Probably first performed in 1598, 2 Henry IV dates from the midpoint between two great plague epidemics in London, in 1593 and 1603, both of which Shakespeare lived through. But although the play was not written in the midst of an outbreak of disease, plague, as Munro (2005: 176) notes "was less cataclysm than context. In the early seventeenth century, London's plague was not a calamitous singularity but a constant presence, ebbing and flowing throughout the year and the years but never disappearing". This context of constant threat is evident in 2 Henry IV which, though it does not deal with plague overtly, teems with imagery of disease and contagion. The play examines moral corruption-that of Falstaff, the rebels and the king himselfthrough the language of physical disease, and not only depicts characters who are really sick (like the king), or "crafty-sick" (like the Earl of Northumberland (Induction, 37)), but also depicts the kingdom itself as diseased. The Archbishop laments that "The commonwealth is sick of their own choice" (1.3.87), having brought down Richard II and raised Bolingbroke up in his place, while the ailing King Henry IV confides anxiously to Warwick, "you perceive the body of our kingdom, /How foul it is, what rank diseases grow, /And with what danger near the heart of it" (3.1.37-39). Edward Berry comments that "From King to commoner England is sick, literally as well as figuratively, the time corrupted and diseased" (1975:106). This conflation of moral and physical corruption echoes the discourse surrounding plague during the sixteenth and seventeenth centuries in which, with the biological causes of the disease poorly understood, it was often interpreted as the result of and the divine punishment for, sinful behaviour. $^{10}$
"[P]lague", says Munro (2005: 177), "is both inside and outside the city: at once alien and (through implication and calendrical repetition) inherent to urban experience". This sense of a threat being both "alien" and "inherent" is echoed in 2 Henry IV in the ambivalence evident in apportioning of blame for the "sickness" of the kingdom: when Henry IV turns to Warwick for counsel about how to deal with the "body of [his] kingdom" endangered by the "rank diseases" that grow "near the heart of it", Warwick suggests that the rebels are responsible, and reassures the king that the country is "but as a body yet distempered/ Which to his former strength may be restored / With good advice and little medicine. / My Lord Northumberland will soon be cooled" (3.1.40-43). In short, Warwick sees something "alien"-rebellion - as being the cause of the kingdom's "distemper", as in 2 Henry VI, when Jack Cade marches on London from Kent, but Henry's assertion that the disease grows near the kingdom's "heart", suggests that it is "inherent" and that the king himself may be the cause of it, a suggestion that is reinforced when the crushing of the rebellion does not cure the king, prompting him to ask the question, "and wherefore should this good news make me sick?" (4.3.102).

Henry IV's ailing body is mirrored in the diseased "body" of his kingdom, highlighting the almost symbiotic relationship between monarch and nation that was accepted during the medieval and early modern periods. ${ }^{11}$ Monteyne's (2007: 75) statement that, "plague attacks the individual body and then progresses into the social body and spaces of the city", suggests that plague infection perhaps replicated this dynamic in the relationship between individual citizens and their social spaces. The idea of plague transforming urban space is well established. Munro (2005: 179) describes plague as "a spatial disease", and claims that "it refigures the living and symbolic space of the city, altering and transforming the urban aspect", while Sanders suggests that early seventeenth-century pamphlet literature by writers such as Thomas Dekker

offer[s] us eye-witness accounts of the new geographies of the city created by each plague epidemic, the cultural cartographies of disease. From the mass graves [...] or the novel signage of the bills of mortality that announced each week's losses to the empty and boarded-up shops and houses, we are invited to walk around these reconfigured spaces' (Sanders, 2011: 208).

While the steady influx of people to London over the course of the sixteenth century caused overcrowding and was blamed for social and moral disorder, both of which were associated in the popular imagination with plague, once the disease took hold, London experienced a rapid exodus as many of those who could afford to leave the city fled the contagion. ${ }^{12}$ This not only transformed the city, leaving it deserted and inhibiting its commercial life, but also signalled that-for the runaways-the city had already transformed imperceptibly before they left, indeed, this transformation was the cause of their flight: once plague struck, London ceased to be a place of trade, safety, entertainment and interaction and become instead a place of threat, to be abandoned if possible. The visible transformation of the city, caused by the mass exodus of many citizens, was the result of an imaginative transformation in the way in which those citizens perceived their city once disease had begun to spread.

Not only did the civic space of the city as a whole change its character during plague epidemics, the domestic and commercial spaces within it did too. As theatres and other places of congregation were closed, those places which had been associated with entertainment and enjoyment, became associated with infection and danger, and, in probably the most striking example 
of the transformation of space, infected households were boarded shut and guarded, with the inhabitants-sick and healthy aliketrapped inside: the ultimate "safe" space (the home) became a threat; the domestic space, became a prison (see Slack, 1989: 169170). To the wider population, this strategy of containment and isolation was vital to protect the surrounding area from contagion, but to the people shut inside these houses, the policy must have seemed like inhuman punishment; a death sentence which "virtually guaranteed", as Slack (1989) says, "contagion between members of a family" (170) who might have escaped infection had they been allowed their liberty. Such tensions occasionally boiled over. Discussing the last great plague outbreak of the seventeenth century, Monteyne (2007: 80) recounts how "[i]n late August and September of 1665, household segregation [...] collapsed. People refused to stay quarantined and broke out of their homes, attacking watchmen and even aldermen [...] A group even tried to shut up the Lord Mayor's house". This potent image of resistance to the attempt to seal up families in their homes in an effort to protect the neighbourhood reinforces the notion that spaces such as the quarantined house are equivocal; simultaneously protective and punitive depending on perspective. It is this fluidity and instability of space with which 2 Henry IV engages so productively, and it does so not only through its settings, but also through its imagery and even syntactical patterning, creating an atmosphere in which inversion and disorientation prevail, and spaces-both geographical and conceptual-which seems at first to be protective or inclusive, are often revealed to be exclusive or punitive. The final section of this article will examine these characteristics of 2 Henry $I V$, and suggest how they might be read as implicitly embedded in contemporary concerns and anxieties about domestic and civic spaces during times of crisis, such as outbreaks of disease, when the psychological and physical geography of London was transformed by fear of contagion, and by the strategies put in place to halt its spread.

\section{Tavern, battlefield and crown: topsy-turvy spaces in 2 Henry IV}

The first line of the play's Induction- "Open your ears; for which of you will stop/ The vent of hearing when loud Rumour speaks"-immediately introduces the idea of permeable, vulnerable orifices being colonised or infected. It anticipates the sense of the ear as a vulnerable opening, which is later exploited in Hamlet (in which King Hamlet is murdered by his brother pouring poison into his ear while he sleeps), while the stage direction that Rumour is to appear "full of tongues" suggests, as well as multiple conflicting voices, multiple mouths breathing infection (a trope that appears again in Coriolanus, in Martius's characterization of the plebeians). When the action of the play proper begins, this image of Rumour's pervasive spread is performed, as Lord Bardolph greets the Porter of Warkworth Castle with the question "Who keeps the gate here?" (1.1.1) In opening the gate, he crosses the physical boundary of the Earl of Northumberland's residence and then permeates the Earl's "vent of hearing" with the news that Hotspur has been victorious at Shrewsbury. But Lord Bardolph is an unwitting embodiment of the "Rumour" of the Induction, and his message is false-it is contradicted almost immediately by the news, brought by Morton, that Hotspur is dead and the rebels defeated. Northumberland responds to this blow with the first of a series of lines in the play that exhibit a kind of chiasmus, turning themselves inside-out. ${ }^{13} \mathrm{He}$ says: "In poison there is physic; and these news, /Having been well, that would have made me sick, /Being sick, have in some measure made me well" (1.1.137-139). This speech pattern re-surfaces occasionally throughout the rest of the play. During Falstaff's exchange with the Lord Chief Justice in act 1, scene 2, when the Justice accuses Falstaff: "You have misled the youthful prince", the fat knight retorts, "the young prince hath misled me", turning the sentence inside-out (1.2.145-146). Again, at the end of the scene, when the Lord Chief Justice prays, "God send the prince a better companion!", Falstaff replies with the reverse, "God send the companion a better prince!"(1.2.199-201). Finally, in 4.3, when he hears the news that the rebels have been defeated, the King exclaims, "And wherefore should these good news make me sick?"(102), reversing Northumberland's reaction to the same news at the beginning of the play.

These utterances highlight how readily different perceptions of situations can co-exist, and how difficult it is to determine who or what is responsible for "contagion" in this play, whether physical or moral, and they prime an audience or reader to be alert to reversal and inversion in the wider structure of the play. For this turning inside-out that exists in the speech of the play is merely a microcosm of more profound inversions which take place when spaces are turned inside-out. In 2 Henry IV, locations which seems to be spaces of liberty, where subversion, disorder and outlaw practices can thrive, are repeatedly revealed to be spaces of containment, surreptitiously controlled by the monarchy. In this way they echo not only the wider relationship of London to its suburbs and liberties, but also the transformation of space, outlined above, which could occur in the city during plague outbreaks in which previously safe spaces, whether public or domestic, became perceived as dangerous. The Boar's Head Tavern at Eastcheap is a prime example of a space which seems to be immune from normal social order. In this tavern Falstaff reigns supreme-eating, drinking, whoring and borrowing money at will. Mistress Quickly, the nominal figure of authority, is overruled, failing first in her attempted legal action to recoup the money Falstaff owes her, and then failing utterly to keep Pistol from crossing the boundary of her establishment despite her command, "Shut the door; there comes no swaggerers here. [...] Your ensign-swaggerer comes not in my doors" (2.4.74-82). It is Falstaff who controls entrances and exits from the tavern, first letting Pistol in, and then driving him out. At first glance, then, the tavern appears to be Falstaff s personal protected space where he can rule (or misrule) immune from social control. Indeed, Grantley (2008: 73) draws attention to the contrast between what he calls Falstaffs "success in his own urban space" with his "cowardice" and "incapacity" on the battlefield. But Falstaff is not really in control in the tavern. The episode in which Prince Hal and Poins disguise themselves as drawers and eavesdrop on Falstaff, then reveal themselves and force him to account for the insults he has heaped on them when he thought that they were not, as he says, "within hearing" (2.4.313-314), demonstrates how, in this play, spaces can masquerade as protected-immune from control and regulation-when in fact they are being used to humble and humiliate, to remind their unruly inhabitants who is in charge. As Munro (2005: 86) says:

Though Falstaff may occasionally attempt to assert his carnivalesque power over Hal, there is never any doubt about who is truly the master of ceremonies at this theater inn. In effect, the court encloses London, and is always available to suppress its riotous energy when it goes past the point of toleration. The perimeters of the Boar's Head are continually patrolled by the guardians of rule, and even within this constrained theatrical space Hal frequently asserts his rank to blunt the edge of Falstaff's disruptive ironies.

Hal rebukes himself for wasting time on such frivolous activities when his father's throne is in danger. But actually this episode is crucial in revealing how spaces in this play are 
equivocal, and it can be viewed as a kind of comedic dry-run for the strategy that is used subsequently to crush the rebellion.

The subterfuge used to trick the rebels at Gaultree works in much the same way as Hal's deception of Falstaff in the tavern. Prince John creates for the rebels a space which he convinces them is safe and protected; a space in which they can express their grievances with immunity from punishment. This geographical space is defined quite specifically at several points in act 4 , scene 1. Westmorland first takes the rebels' written list of grievances, and tells them, "This will I show the general. Please you, lords, In sight of both our battles we may meet, / At either end in peace ..." (4.1.176-178). Later the place of meeting is made even more specific, as he tells Mowbray, "The prince is here at hand. Pleaseth your lordship / To meet his grace at just distance 'tween our armies?" (4.2.223-224). Finally, Prince John himself agrees to the rebels' demands and proposes: "here between the armies / Let's drink together friendly and embrace ..." (4.2.288-289) [my emphases]. The specific location of the meeting is important-the "just distance" between the opposing armies suggests equality; a space in which, perhaps, the king's usual dominance does not apply. But again this is not the case. Like Falstaff's tavern the battlefield's perimeters are, in Munro's words, "continually patrolled by the guardians of rule", and once Prince John has tricked the rebels into dismissing their forces, they are rounded up and captured by the king's men. The space of seeming liberty turns out to be a space of containment.

By this point in the play, it is difficult to see any spaces which are not in some way controlled by monarchical power. The whole of London, and indeed the whole of the kingdom seems to be camera regis, the chamber of the monarch. ${ }^{14}$ Potentially disruptive spaces are turned inside-out and revealed to contain and neutralise that disruption. This feature of the play might have spoken to audience members concerned about bringing the supposed riotousness of the suburbs under control and ensuring that it did not spread to the city-proper, as well as those who feared the institutions and regulations of the city encroaching on the freedoms the suburbs and liberties enjoyed, and-if the political disorder of the play is read as analogous to disease, as the play's imagery encourages-it may also echo the hope that civic authorities could stop the transmission of infection by strategies of the kind described by Slack (1990: 199-216), that the ineluctable and unknowable disease which periodically decimated the city could be quantified, understood and brought under control. However, in the last stages of the play, when the action moves to the literal camera regis-the private rooms in which Henry IV lies on his sickbed-it becomes clear that here, as in the early modern city of London, disruption and disease can neither conclusively be banished or safely contained: they exist at the heart of the kingdom as well as at its perimeters; in its king as well as in its rebels and ruffians. The crown, which the future Richard III describes in 3 Henry VI, as containing "within [its] circuit [...] Elysium" (1.2.30)-an image that encourages us to view the crown as itself defining a space-is here figured as the cause of the king's deterioration, and the instigator of a physical decay which threatens to annihilate his body, breaking down the boundaries that delineate his very person. As Clarence says:

...he cannot long hold out: these pangs.

Th'incessant care and labour of his mind

Hath wrought the mure that should confine it in

So thin that life looks through and will break out. (4.3.117120)

This image is in many ways a reworking of Richard II's meditation on the mortality of kings: ...within the hollow crown

That rounds the mortal temples of a king

Keeps death his court; and there the antic sits,

Scoffing at his state and grinning at his pomp,

Allowing him a breath, a little scene,

To monarchize, be feared, and kill with looks,

Infusing him with self and vain conceit,

As if this flesh which walls about out life

Were brass impregnable; and humoured thus,

Comes at the last, and with a little pin

Bores through the castle wall; and farewell, king. (RII, 3.2.156166)

In both cases the king's body is figured as a walled enclosure, but while in Richard II, death comes in from outside, in 2 Henry IV, the process is inverted-the walls are worn down from inside, and life "breaks out". The crown-the symbolic power of which the king uses to attempt to bind the kingdom together and to stop it fragmenting and subdividing into opposing factions-is the agent of his own fragmentation and physical decay.

This idea of the crown as an equivocal, subjective, imaginative space finds its most concrete and precise expression in Prince Hal's speech at his father's bedside in 4.2. He begins by echoing his brother Clarence's lament that cares of state-symbolised by the crown-have left his father's body open and undefended: "O polished perturbation, golden care, /That keep'st the ports of slumber open wide / to many a watchful night!" (4.3.154-156). However, a few lines later he refines this idea, and comes up with a simile that encapsulates the idea of the crown as simultaneously protective and damaging in a more profound way:

O majesty,

When thou dost pinch thy bearer, thou dost sit

Like a rich armour worn in heat of day,

That scald'st with safety. (4.3.159-162)

"Scalding with safety" is a phrase that chimes, ominously, with the practice of quarantining infected houses during plague epidemics, in which the strategy of containing and isolating the infected household aims to protect the community at the expense of the household's inhabitants. The word "scalding" also resonates specifically with systems put in place to curb the spread of infection, as these often involved burning: fires were lit in the streets "to dispel infected air" while "[b]urning incense or rosemary might have the same effect in a house", and "the clothes and bedding of the sick" was also burned (Slack, 1990: 30). The crown, then, is like the other spaces this section has considered. Like the battlefield at Gaultree where the rebels believe they can express their grievances with impunity, or the tavern, which Falstaff believes is his private domain, it appears at first glance protective, liberating, a source of power and immunity, but this notion is quickly turned inside out, and it turns out to be a source of punishment and subjection, at least for Henry IV who has gained it through usurpation rather than rightful inheritance.

The dying Henry IV's most idealistic hopes and worst fears for his kingdom also find expression in images of rigid containment and uncontrolled fluidity. His hope is that his son, Thomas Clarence, will hold his other sons together in an impermeable, protected and sealed union, which will defy all attempts to weaken it:

...thou shalt prove $[\ldots]$

A hoop of gold to bind thy brothers in, 
That the united vessel of their blood,

Mingled with the venom of suggestion -

As force perforce the age will pour it in -

Shall never leak ... (4.3.42-47)

The king's dearest hope-as he himself is disintegrating-is that his sons will remain whole, but the metaphor that he chooses - the hoop of gold which binds-is semantically so close to that other golden hoop-the crown that pinches and scalds-that the image of the brothers bound together in an un-leaking, impervious unit is somewhat sinister. Moreover, the play's engagement with spaces has been so predicated on fluidity and instability that the "hoop of gold" binding together the unleaking, united vessel seems doomed to fail. The play has primed us to mistrust boundaries and expect that the spaces it presents to us will shift and change before our eyes, in a way which might have seemed familiar to its original audiences who were aware of the physical and imaginative transformations the spaces of their city underwent when plague swept through it. Henry's worst fears, on the other hand, which he thinks will be realised when Hal takes the crown from his pillow, are expressed in the images of uncontrolled movement with which this article began: the leakage of the scum of the world into a court, which is no longer a protected space. But the variability of imaginative space is at play here too, and Henry's nightmare-that England will become one giant space of liberty, where disorder is immune from control -is Falstaff's dream, and he believes it has come true when he hears that Hal has ascended throne. "Let us take any man's horses" he says, "the laws of England are at my commandment" (5.3.134-136). Falstaff believes briefly that the whole kingdom has become his own personal space of liberty, but his banishment from Hal's presence crushes that hope and turns the rest of England into a barren and unprofitable place for him. As Dillon says, Falstaff "is on the margin, where he has in a sense always been in the new King's mind, even in the tavern, [...] he is expecting to move to the centre of government, by stepping into the role of Lord Chief Justice [...] but it is not to be" (Dillon, 2012: 28).

Shakespeare's play returns repeatedly to ideas of inversion: bad news makes Northumberland well, and good news makes King Henry ill; the battlefield at Gaultree changes from a neutral space between the opposing factions in which the rebels believe they can express their grievances against the crown without fear of redress to a space in which they are surrounded and imprisoned by the King's forces; and the crown itself is figured as a claustrophobic, paradoxical suit of armour on a hot day, which "scalds with safety", simultaneously protecting and damaging. This emphasis on inversion is coupled with an interest in boundaries, demarcations and boundary infringement: the ailing king is described as a disintegrating container, so fragile that his life might "break out" at any moment; conversely he longs for his sons to form a "united vessel" bound by a "hoop of gold" that "shall never leak", but fears that Hal's reign will herald the opposite-an indiscriminate tidal wave of "scum" from "every region"; and finally the play ends with the new king, Henry V, banishing his "misleaders" into an ill-defined, peripheral space that exists only in relation to the king's own body. All of these factors resonate with the swift transformations of civic and domestic spaces experienced by early modern citizens during epidemics and, more generally, with the ambivalent attitudes of the crown, the city fathers and citizens towards the rapidly growing population of London and the relationship of the sprawling, over-crowded, but energetic and economically vibrant suburbs with the established cityproper.

\section{Conclusions}

The spatial relations of early modern London were complex. On the one hand, there was a tendency in literature to highlight binary distinctions between city and suburbs as places of order versus disorder; on the other, evidence of brothels, playhouses and other potentially "disorderly" enterprises and behaviours inside as well as outside the city walls, and the constant movement of people between these two areas, suggest that the lived experience of the city did not reflect such a distinction, and that perceptions and experiences of the various spaces of the city were fluid and dependent on context. Plague outbreaks both reinforced this distinction, by encouraging people to fear the "sinfully polluted suburbs", and dismantled it, as the disease crossed boundaries of wall, ward and parish, and highlighted the fluidity and subjectivity of the experience of urban space, forcing people to flee the city and turning spaces of safety and comfort into spaces of fear and suspicion. In short, the spatial relations of early modern London were brought into sharp focus by moments of crisis such as plague outbreaks. 2 Henry IV also highlights binary distinctions between spaces, and then dismantles them: it sets up tavern and battlefield as locations where challenges to civic order and monarchical authority might prosper and then reveals them to be firmly under the control of the crown, only to undermine this control by depicting the king as a site of disorder and the crown itself an equivocal imaginative space. Even the play's final spatial image-that of the new king ordering Falstaff not to come within ten miles of him-is equivocal. If it is read as a kind of isolation or quarantine, enclosing the king in a "safe zone", then it raises ambiguities of the kind discussed by Stanev in relation to Martius's isolation from the plebeians in Coriolanus: "By quarantining oneself, one not only signals a desire to keep the pestilence out, but evokes fears in one's neighbours that one might already have been visited by the sickness" (Stanev, 2014: 175). Henry V's admonition to Falstaff "not to come near" him "on pain of death" raises the question of which of them is really the morally infectious agent, and reminds us of Falstaffs chiasmic exchange with the Lord Chief Justice in Act 1: LCJ: "You have misled the youthful prince", Falstaff: "the young prince hath misled me" (1.2.145-46). The play's insistent conflation of civil unrest and disease, coupled with its emphasis on isolation, containment and boundary infringement suggests that preoccupation with the civic space of the capital and underlying anxiety about the plague and its ability to turn both public and private spaces into places of suspicion, fear and mistrust, helped to shape this drama. Munro (2005: 192) argues that "to write of the plague is inevitably to create divisions between private and public and between the individual and the society. Plague, however, creates such categories only to transgress them; the oppositions cannot be held separate and always collapse into each other". We might usefully think of 2 Henry $I V$ in the same terms: it creates geographical and symbolic spaces and turns them inside-out, rendering them disorienting, unpredictable and often threatening.

2 Henry IV is not ostensibly "about" early modern London, but this article has suggested that it can certainly be read as "making sense" of the space of the capital-making sense not of specific literal locations, as many city comedies do, but of the experience of spaces -in ways, which align it clearly with pressing contemporary concerns. Crawforth et al. (2015: 2) state at the outset of their book that "[i]t is a notorious fact that Shakespeare rarely writes about London directly, and yet his life was enmeshed with that of his adopted city", and they go on to argue persuasively that "[u]nderstanding the important presence of this exhilarating city within his work can [...] help us to read his plays anew, to capture something of the freshness of the moment-and the place-in which they were written". This article has suggested that the approaches used by recent critics, such as Crawforth, Dustagheer and Young, to uncover the traces of London life embedded in Shakespearean plays 
set elsewhere, can also be productively applied to a history play like 2 Henry IV, which is sometimes in danger of being overlooked because its relationship to London can seem, at first glance, once of uncomplicated setting alone. In fact, it is not in its location of scenes in Eastcheap or Westminster that this play reveals its immersion in the early modern London of its production, but in its discourse of disease, its imagery of boundaries and containment, and its repeated evocation of fluid and equivocal spaces.

\section{Notes}

1 "Cultural geography" is a notoriously broad concept, and one which has different meanings and connotations within different disciplines, but for the purposes of this article, Crang's (1998: 3) definition is helpful: "Cultural geography looks at the way different processes come together in particular places and how those places develop meanings for people. [...] cultural geography is about the diversity and plurality of life in all its variegated richness; about how the world, spaces and places are interpreted and used by people; and how those places then help to perpetuate that culture".

2 See, for example, Dillon (2000); Sanders (2011); Howard (2009); Stanev (2014); Turner (2006); Grantley (2008); Crawforth et al. (2015).

3 See, for example, Stanev (2014) on Timon of Athens and Coriolanus.

4 Like "cultural geography", the term "spatial relations" is broad and can encompas and mean different things in different disciplines. I use it to mean what Sanders (2011: 9-10) describes as "the complex interactions that take place between people and the spatial structures and concepts [...] that shape their understanding and practice of the world".

5 First printed in 1600, 2 Henry IV is thought to date from 1597-98. Bate and Rasmussen (2007: 899), in The RSC Shakespeare: William Shakespeare Complete Works suggest that "it must have been written after The First Part (1596-97) and before Henry V (early 1599)".

6 All quotations from Shakespeare's plays are from Wells and Taylor (2005). William Shakespeare: the Complete Works.

7 A 1598 Star Chamber case, prosecuting two men under the 1580 proclamation, "claims that 'the City of London, and Suburbs thereof, are ouercharged, and burdened with sundry sorts of poor, beggarly, and euill disposed persons, to the great hindrance and oppression of the same' "' (Munro, 2005: 21).

8 See Archer (1991: 211) and Griffiths (1993: 54).

9 On the perceived sinfulness of the suburbs and the links between prostitution and the theatres, see Howard (2009: 122-127); on the historical association of the suburbs with hospitals and so on, see Healy (2007); on the association of the suburbs with plague, see Slack (1990: 26 and 152-164).

10 This logic was neatly summarized by puritan preacher Thomas White in a sermon of 3 November 1577, in which he argued that 'the cause of plagues is sin, if you look to it well, and the cause of sin are plays; therefore the cause of plagues are plays. Even Thomas Dekker (a dramatist and therefore the cause of the plays that caused the sin that caused the plague), in his 1603 work, The Wonderfull Yeare, personifies the plague as "Death (like a Spanish Leagar, or rather like stalking Tamberlaine) [who] hath pitcht his tents [...] in the sinfully-polluted Suburbes" (D1r sig.), acknowledging (whether sincerely or not) the assumed connection between moral and physical illness.

11 See, for example, Sir Thomas Smith, De Republica Anglorum, "To be short the prince is the life, the head, and the authoritie of all things that be done in the realme of England" (1583: 47)

12 For details of the range of contemporary attitudes to these so-called "run-aways", see Slack (1990: 41-44) and Monteyne (2007: 85-94).

13 Crawforth, Dustagheer and Young identify this rhetorical device in Richard II too, arguing that "the language of the play displays at a local level the same organizational principles, the same fondness for doubling and reversals, which its larger structure also embodies" (2015: 62), and linking it to the reversals of political fortune experienced by Richard and Bolingbroke. It is clear that this microcosmic and macrocosmic interest in reversal and inversion extends into the Henry IV plays, but in 2 Henry IV, I think, it is more specifically and noticeably articulated through the way that the experience of spaces is reversed or turned inside-out.

14 For detailed discussion of London as camera regis, see Munro, 77-89.

\section{References}

Archer I (1991) The Pursuit of Stability: Social Relations in Elizabethan London. Cambridge University Press: Cambridge, UK.

Atwood EK (2013) “All places are alike”: Marlowe's Edward II and english spatial imagination. Journal of Medieval and Early Modern Studies; 43 (1): 49-70.

Bate J and Rasmussen E (eds) (2007) The RSC Shakespeare: William Shakespeare Complete Works. Palgrave Macmillan: Basingstoke, UK.

Berry E (1975) Patterns of Decay: Shakespeare's Early Histories. University Press of Virginia: Charlottesville, VA.

Crang M (1998) Cultural Geography. Routledge: London.
Crawforth H, Dustagheer S and Young J (2015) Shakespeare in London. Bloomsbury Arden Shakespeare: London.

Dekker T (1603) The Wonderfull Yeare: Wherein is Shewed the Picture of London Lying Sicke of the Plague. Thaoms Creede: London, Early English Books Online, 5 July 2016.

Dillon J (2000) Theatre, Court and City, 1595-1610: Drama and Social Space in London. Cambridge University Press: Cambridge, UK.

Dillon J (2012) Shakespeare and the Staging of English History. Oxford University Press: Oxford.

Dustagheer S (2013) Shakespeare and the "spatial turn". Literature Compass; 10 (7): 570-581.

Grantley D (2008) London in Early Modern English Drama: Representing the Built Environment. Palgrave Macmillan: Baskingstoke, UK.

Griffiths P (1993) The structure of prostitution in Elizabethan London. Continuity and Change; 8 (1): 39-63.

Healy M (2007) Highways, hospitals and boundary hazards. In: Betteridge T (ed.), Borders and Travellers in Early Modern Europe. Ashgate: Aldershot, UK.

Howard J (2009) Theater of a City: The Places of London Comedy, 1598-1642. University of Pennsylvania Press: Philadelphia, PA.

Jonson B (1610) The Alchemist. In: Jamieson M (ed.) (1966) Three Comedies. Penguin: London.

Lefebvre H (1974) The Production of Space; Translated by D Nicolson-Smith (1991) Blackwell: Oxford.

Manley L (1995) Literature and Culture in Early Modern London. Cambridge University Press: Cambridge, UK.

Monteyne J (2007) The Printed Image in Early Modern London: Urban Space. Visual Representation and Social Exchange. Ashgate: Aldershot, UK.

Mullaney S (1988) The Place of the Stage: License, play, and Power in Renaissance England. The University of Chicago Press: London.

Munro I (2005) The Figure of the Crowd in Early Modern London: The City and its Double. Palgrave Macmillan: Basingstoke, UK.

Newman K (2007) Cultural Capitals: Early Modern London and Paris. Princeton University Press: Oxford.

Sanders J (2011) The Cultural Geography of Early Modern Drama, 1620-1650. Cambridge University Press: Cambridge, UK.

Slack P (1989) The response to plague in early modern England: Public policies and their consequences. In: Walter J (ed.), Famine, Disease and the Social Order in Early Modern Society. Cambridge University Press: Cambridge, UK.

Slack P (1990) The Impact of Plague in Tudor and Stuart England. Oxford University Press: Oxford.

Smith T (1583) De Republica Anglorum The Maner of Gouernement or Policie of the Realme of England, Compiled by the Honorable Man Thomas Smyth, Doctor of the Ciuil Lawes, Knight, and Principall Secretarie vnto the Two Most Worthie Princes, King Edwarde the Sixt, and Queene Elizabeth. Seene and Allowed. Henrie Midleton: London, Early English Books Online, Accessed 13 September 2016.

Stanev HA (2014) Sensory Experience and the Metropolis on the Jacobean Stage. Ashgate: Farnham, UK.

Turner HS (2006) The English Renaissance Stage: Geometry, Poetics and the Practical Spatial Arts 1580-1630. Oxford University Press: Oxford.

Ward J (1997) Metropolitan Communities: Trade guilds, Identity and Change in Early Modern London. Stanford University Press: Stanford, CA.

Wells S and Taylor G (eds) (2005) William Shakespeare: The Complete Works. Oxford University Press: Oxford.

White T (1577) A Sermon[n] Preached at Pawles Crosse on Sunday the Thirde of Nouember 1577. In the Time of the Plague. T.W.: London, Early English Books Online, 11 August 2015.

\section{Data availability}

Data sharing not applicable to this article as no datasets were generated or analysed during the current study.

\section{Additional information}

Competing interests: The authors declare no competing financial interest.

Reprints and permission information is available at http://www.palgrave-journals.com/ pal/authors/rights_and_permissions.html

How to cite this article: Knowles K (2016) "Not to come near our person by ten mile": London, plague and spatial relations in 2 Henry IV. Palgrave Communications. 2:16076 doi: $10.1057 /$ palcomms.2016.76.

This work is licensed under a Creative Commons Attribution 4.0 International License. The images or other third party material in this article are included in the article's Creative Commons license, unless indicated otherwise in the credit line; if the material is not included under the Creative Commons license, users will need to obtain permission from the license holder to reproduce the material To view a copy of this license, visit http://creativecommons.org/licenses/by/4.0/ 